\title{
ANALISIS PEMBIAYAAN MUDHARABAH BERMASALAH PADA BMT MITRA HASANAH SEMARANG
}

\author{
Odi Nur Arifah \\ D-III Akuntansi \\ Universitas Islam Sultan Agung Semarang \\ odinurarifah@gmail.com
}

\begin{abstract}
Abstrak
$\mathrm{P}$ roblematika kehidupan manusia selalu dilatarbelakangi oleh keadaan perekonomian yang semakin sulit. Mulai dari petani kecil, pengusaha kecil, pedagang kecil dan semua kegiatan yang berskala kecil. Mereka membutuhkan suatu bantuan dana untuk memfasilitasi bisnis mereka, maka BMT Mitra Hasanah Semarang mengembangkan produknya yaitu pembiayaan Mudharabah sesuai dengan perkembangan dunia perbankan dalam target peningkatan keuntungan dan menyejahteraan masyarakat. Dengan diberikannya pembiayaan tersebut, terkadang muncul adanya pembiayaan yang bermasalah yang disebabkan oleh adanya ketidakmampuan anggota untuk membayar tepat waktu atau jatuh tempo pembayaran dan terkadang diakibatkan dari usaha yang kurang lancar, dan lainlain. Adapun cara untuk menangani pembiayaan mudharabah bermasalah ini antara lain Rescheduling, Restructing, dan Reconditioning.
\end{abstract}

Kata Kunci: Pembiayaan Mudharabah Bermasalah, Rescheduling, Restructing, dan Reconditioning

\section{Pendahuluan}

BMT (Baitul Maal wa Tamwil) atau yang sekarang sudah berganti nama menjadi KSPPS (Koperasi Simpan Pinjam dan Pembiayaan Syariah) pada dasarnya bukan merupakan suatu lembaga Perbankan murni, melainkan Lembaga Keuangan Mikro Syariah yang mana sebagian dari Sistem Operasional pelaksanaannya menyerupai Sistem Operasional Perbankan Syariah pada umumnya. Kehidupan masyarakat yang saat ini dapat dikatakan serba kecukupan, dikhawatirkan dapat memunculkan suatu pengikisan akidah. Hal ini tentu tidak hanya dipengaruhi oleh perekonomian masyarakat yang lemah, maka dari itu untuk mengatasi masalah yang ada, BMT diharapkan dapat membantu mengatasinya melalui pemenuhan kebutuhan ekonomi masyarakat.

Setiap BMT tentu memiliki produk-pruduk yang ditawarkan. Produk tersebut berupa simpanan dan pembiayaan. Sedangkan di BMT Mitra Hasanah terdapat berbagai macam produk pembiayaan yang ditawarkan, akan tetapi produk yang paling diminati adalah Pembiayaan Mudharabah. Pembiayaan Mudharabah adalah perjanjian antara dua pihak dimana pihak pertama sebagai pemilik dana (shahibul mal) dan pihak kedua sebagai pengelola dana (mudharib) untuk mengelola suatu kegiatan ekonomi dengan menyepakati nisbah bagi hasil atas keuntungan yang akan diperoleh, sedangkan kerugian yang timbul adalah resiko pemilik dana sepanjang tidak terdapat bukti bahwa mudharib melakukan kecurangan atau tindakan yang tidak amanah

Syarat atau jaminan pembiayaan mudharabah di BMT Mitra Hasanah antara lain BPKB kendaraan, sertifikat tanah, surat pasar, dan tabungan. Seiring berjalannya waktu, terdapat masalah yang timbul dari pembiayaan mudharabah di BMT Mitra Hasanah, sehingga masalah yang timbul ini dinamakan dengan Pembiayaan Bermasalah. Pembiayaan bermasalah merupakan suatu peminjaman dana yang tertunda atau ketidak mampuan peminjam untuk mengembalikan dana atau kewajiban yang telah dibebankan kepadanya. Timbulnya masalah ini dapat berawal dari bagaimana pelaksanaan usaha yang telah dibiayai oleh BMT Mitra Hasanah, apakah pengelola dana (mudharib) benar-benar menjalankan usahanya sesuai dengan yang disebutkan 
dalam kontrak ataupun si pengelola dana tersebut telah ingkar kepada BMT Mitra Hasanah.

Pokok persoalan yang ada pada pembiayaan bermasalah adalah tidak sesuaianya atau tidak mampuanya seorang peminjam memperoleh pendapatan untuk melunasi pembiayaan yang telah dipinjamnya dari BMT. Usaha penanganan dari masalah ini yaitu dengan menggunakan Prinsip 3R (Rescheduling, Restructuring, dan Reconditioning). Tanpa adanya upaya ini maka kemungkinan pembiayaan mudharabah bermasalah yang ada di BMt Mitra Hasanah akan semakin bertambah.

Berdasarkan masalah tersebut maka dalam penelitian ini dilakukan pengujian terhadap pembiayaan mudharabah bermasalah di BMT Mitra Hasanah Semarang dengan judul penelitian "ANALISIS PEMBIAYAAN MUDHARABAH BERMASALAH PADA BMT MITRA HASANAH SEMARANG”.

\section{Pembahasan}

\section{Fatwa Tentang Pembiayaan Mudharabah}

Rukun dan syarat akad mudharabah yaitu :

a. Penyedia dana (shahibul maal) dan pengelola dana (mudharib) harus cakap hukum.

b. Persyaratan ijab dan qobul harus dinyatakan oleh para pihak untuk menunjukkkan kehendak mereka dalam mengandakan kontrak (akad) dengan memeprhatikan hal-hal berikut :

1) Penawaran dan penerimaan harus secara eksplisit menunjukkan tujuan kontrak (akad)

2) Penerimaan dan penawaran dilakukan pada saat kontrak

3) Akad dituangkan secara tertulis, melalui korespondensi, atau dengan menggunakan cara-cara komunikasi moderen.

c. Modal adalah sejumlah uang dan atau aset yang diberikan oleh penyedia dana kepada mudharib untuk tujuan usaha dengan syarat sebagai berikut :

1) Modal harus diketahui jumlah dan jenisnya

2) Modal dapat berbentuk uang atau barang yang dinilai. Jika modal diberikan dalam bentuk aset, maka aset tersebut harus dinilai pada waktu akad.

3) Modal tidak dapat berbentuk piutang dan harus dibayarkan kepada mudharib, baik secara bertahap maupun tidak, sesuai dengan kesepakatan dalam akad.

d. Keuntungan Mudharabah, yaitu jumlah yang didapat sebagai kelebihan dari modal. Syarat keuntungan ini harus dipenuhi :

1) Harus diperuntukkan bagi kedua pihak dan tidak boleh diidyaratkan untuk satu pihak

2) Bagian keuntungan proporsional bagi setiap pihak harus diketahui dan dionyatakan pada waktu kontrak dan harusb dalam bentuk prosentase (nisbah) dari keuntungan sesuai kesepakatan. Perubahan nisbah harus berdasarkan kesepakatan.

3) Penyedia dana menanggung semua kerugian akibat dari mudharabah, dan pengelola tidaik boleh menanggung kerugian apapun kecuali diakibatkan dari kesalahan disengaja, kelalaian, atau pelanggaran kesepakatan.

e. Kegiatan usaha oleh pengelolan (mudharib), sebagai pertimbangan modal yang disediakan oleh penyedia dana, harus memperhatikan hal-hal berikut:

1) Kegiatan usaha adalah hak eksklusif mudharib, tanpa campur tangan penyedia dana, tetapi ia mempunyai hak untuk melakukan pengawasan.

2) Penyedia dana tidak boleh mempersempit tindakan pengelola sedemikian rupa yang dapat menghalangi tercapainya tujuan mudharabah, yaitu keuntungan.

3) Pengelola tidak boleh menyalahi hukum syariah Islam dalam tindakkannya yang berhubungan dengan mudharabah, dan harus mematuhi kebiasaan yang berlaku dalam aktivitas itu. 


\section{Analisa Pembiayaan Mudharabah di BMT Mitra Hasanah Semarang}

Tiga aspek penting dalam pembiayaan yakni Aman, Lancar, Menguntungkan. Berikut pemaparannya :

a. Aman, yakni keyakinan bahwa dana yang telah dilempar dapat ditarik kembali sesuai dengan kesepakatan.

b. Lancar, yaitu dana yang dilemparkan oleh BMT Mitra Hasanah bisa berputar dengan lancar dan cepat. Karena semakin cepat dan lancar perputaran dananya, maka pengembangan BMT Mitra Hasanah Semarang semakin baik.

c. Menguntungkan, yaitu perhitungan dan proyeksi yang tepat untuk memastikan bahwa dana yang dilempar akan menghasilkan pendapatan.

Selain aspek tersebut, hal yang harus diperhatikan juga adalah bagaimana penerapan prinsip 5C serta 4P di BMT Mitra Hasanah sebelum memberikan pembiayaan kepada anggotanya. Prinsip 5C terdiri dari :

a. Character (akhlak), yaitu penilaian terhadap karakter nasabah untuk memprediksi kemampuan dan kemauan nasabah dalam mengembalikan pembiayaan.

b. Capacity (kemampuan), penilaian secara subjektif tentang kemampuan debitur untuk melakukan pembayaran atau pengembalian pembiayaan dengan melihat catatan prestasi debitur dimasa lalu disertai pengamatan lapangan atas usaha, cara berusaha dan tempat usaha nasabah.

c. Capital (permodalan), yaitu penilaian terhadap kemampuan modal yang dimiliki oleh calon debitur yang diukur dengan posisi usahanya secara keseluruhan melalui rasio finasialnya dan penekanan pada komposisi modalnya.

d. Collateral (jaminan), yaitu jaminan milik calon debitur yang dinilai transaksi sesuai dengan harga pasar untuk mendukung plafond pembiayaan yang diusulkan.

e. Condition (keadaan), yaitu kondisi perekonomian secara makro maupun mikro, terutama komoditas jenis usaha nasabah calon debitu apakah prospektif atau tengah mengalami kelesuan.

Selain prinsip 5C, untuk mengetahui kondisi calon peminjam dana dapat dilakukan dengan menggunakan prinsip 4P yang meliputi :

a. Personality (akhlak calon penerima pembiayaan)

b. Purpose (kegunaan pembiayaan diajukan)

c. Prospect (harapan, keuntungan proyek yang dibiayai)

d. Payment (darimana dan bagaimana pengembalian pembiayaan dilakukan)

\section{Analisis Penangangan Terhadap Pembiayaan Mudharabah Bermasalah di BMT Mitra Hasanah Semarang}

Salah satu produk yang ada di BMT Mitra Hasanah adalah pembiayaan mudharabah. Adanya pembiayaan ini diharapkan akan memperoleh keuntungan bagi hasil atau margin. Pembiayaan seperti itu tentunya tidak akan terlepas dari permasalahan atau resiko-resiko yang timbul yaitu pembiayaan macet, atau angsuran tersendat-sendat. Apabila pembiayaan mulai bermasalah upaya untuk penyelamatan usaha anggota dalam pembiayaan Mudharabah bermasalah di BMT Mitra Hasanah adalah 3R (Rescheduling, Reconditioning, dan Restructuring).

Apabila dari 3 cara tersebut belum bisa ditangani, maka tindakan terakhir adalah mengeksekusi jaminan. Adapun analisis dari kelebihan, kelemahan, peluang, ancaman pada akad Mudharabah di BMt Mitra Hasanah adalah sebagai berikut :

a. Pembiayaan Mudharabah pada BMT Mitra Hasanah mempunyai kelebihan yang lebih fleksibel dan presentasenya kecil. Maka anggota bisa lebih mudah menjangkau angsurannya. 
b. Kelemahan pembiayaan mudharabahnya terletak pada praktek, dimana terjadinya kekurang maksimalan nisbah bagi hasil dalam syari'ah dan terbenturnya dalam realita masyarakat. Harapan BMT Mitra Hasanah, semua karyawan dapat mendalami serta memahami tentang teori syari'ah beserta prakteknya.

c. Peluang pembiayaan mudharabah di BMT Mitra Hasanah yaitu sangat dibutuhkan oleh semua umat pada khususnya umat Islam yang membutuhkan dana untuk membuat suatu usaha.

d. Ancaman dari pembiayan mudharabah di BMT Mitra Hasanah yaitu lembaga keuangan yang sangat pesat berkembang apalagi lembaga keuangan non syari'ah yang menggunakan tawaran yang lebih canggih untuk menarik minat calon anggota atau nasabah. Maka harapan BMT Mitra Hasanah harus bisa melebihi dari itu salah satunya dengan cara membantu dalam usaha anggotanya.

Berdasarkan hasil wawancara penulis dengan Ibu Richaul Wardah, A.Md selaku akunting BMT Berkah Mitra Hasanah, tahapan pengajuan pembiayaan mudharabah di BMT Berkah Mitra Hasanah Semarang dilihat dari karakter nasabah itu sendiri. Karakter itu bisa dilihat dari kejujuran, kesungguhan, dan melengkapi persyaratan-persyaratan yang diajukan oleh pihak BMT Berkah Mitra Hasanah Semarang kepada calon nasabahnya, salah satunya pembiayaan digunakan untuk apa, usaha apa yang dilakukan, dimana lokasi usaha yang dijalankan. Adapun sistem dan prosedur dalam pembiayaan adalah:

a. Harus menjadi anggota (kewajiban menjadi anggota adalah menyetor simpanan wajib sebesar Rp. 10.000).

b. Memepunyai usaha dan penghasilan.

c. Melengkapi semua berkas keterkaitan pengajuan pembiayaan (copy KTP, KK, surat nikah, jaminan / agunan).

Alur pengajuan pembiayaan di BMT Berkah Mitra Hasanah Semarang:

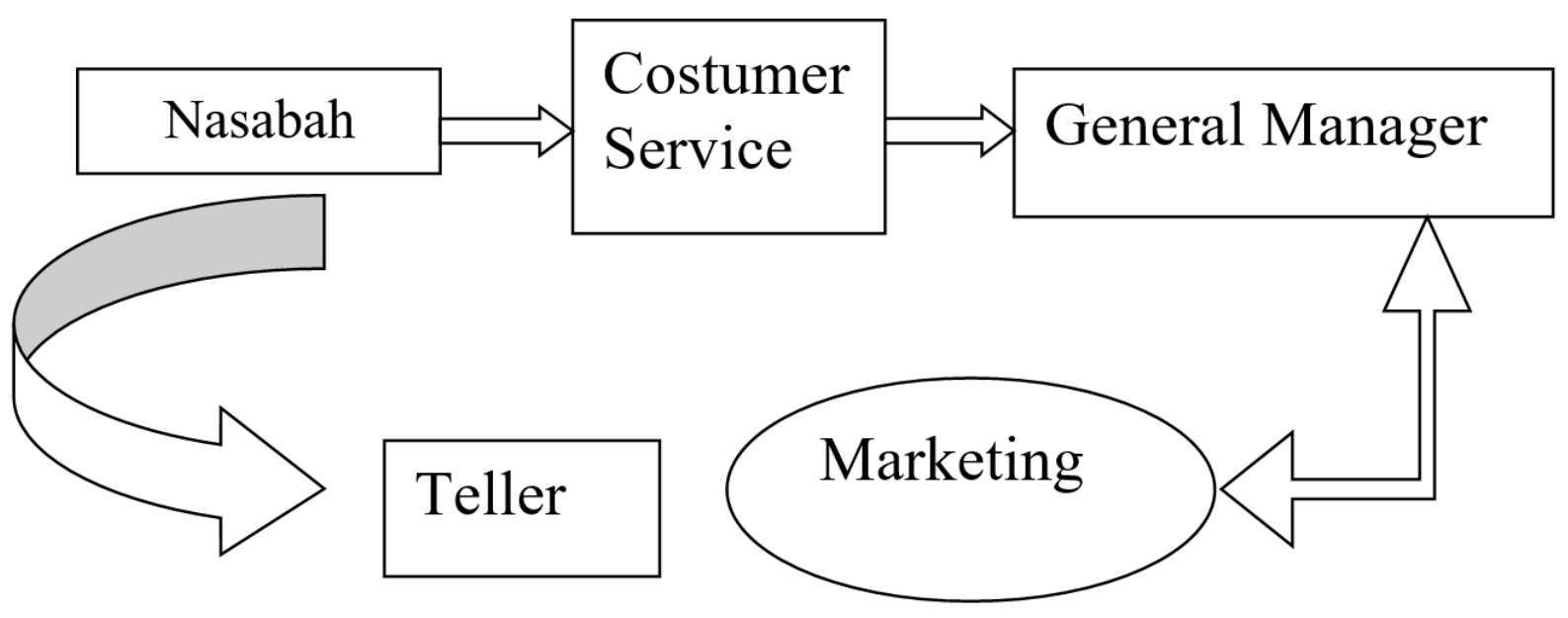

Keterangan:

a. Nasabah atau pemohon datang ke BMT Berkah Mitra Hasanah Semarang menuju ke CS dengan mengisi form pembiayaan dan menyerahkan syarat-syarat pembiayaan, seperti fotocopy KTP, KK, dan lain-lain.

b. Setelah mengisi persyaratan pembiayaan mudharabah nasabah langsung menuju ke bagian pembiayaan untuk memeriksa kelengkapan syarat-syarat pembiayaan dari nasabah dan menanyakan kegunaan pembiayaan dan usaha apa yang kan dijalankan oleh nasabah.

c. General Manager mengkonfirmasikan marketing untuk melakukan survei di lokasi 
tempat usaha, mengetahui bagaimana karakter nasabah dan sekaligus menganalisis jaminan untuk menguatkan pembiayaan. Dilihat dari nyata atau tidak usaha yang dibuat pembiayaan dan ada tidaknya kemungkinan-kemungkinan yang terjadi seperti kemacetan dalam usaha yang disebabkan ketidakjelasan usahanya. Setelah jaminan dan lokasi usaha sudah dipersetujui oleh General Manager, maka alur selanjutnya General Manager akan membuatkan surat realisasi pada pencairan dana.

d. Setelah nasabah mendapat keterangan realisasi dari General Manager maka nasabah menuju ke teller untuk melakukan pencairan dana. Teller akan memberi pencairan dana pembiayaan kepada nasabah dari jumlah yang tertera pada kontrol atau slip realisasi dan sekaligus teller akan meminta uang dari nasabah guna membayar administrasi pembiayaan sesuai pada akad.

\section{Faktor Penyebab Pembiayaan Mudharabah Bermasalah}

Secara umum, faktor-faktor yang mempengaruhi dan menyebabkan terjadinya pembiayaan mudharabah bermasalah adalah sebagai berikut:

a. Faktor Internal

1) Biasanya marketing lupa menagih dan mengingatkan pelanggan.

2) Terjadinya pergantian marketing.

3) Penyaluran dana yang kurang jelas untuk apa pembiayaan itu digunakan.

b. Faktor Eksternal

1) Paling banyak karena usaha anggota yang sepi sehingga mengakibatkan perekonomian menurun.

2) Ada anggota yang mempunyai niat tetapi tidak memiliki dana untuk membayar kewajibannya.

3) Ada anggota yang mempunyai dana untuk membayar kewajibannya tetapi tdak memiliki niat untuk membayarnya.

\section{Penyelamatan Pembiayaan Mudharabah Bermasalah}

Selain upaya untuk menangani pembiayaan mudharabah bermasalah biasanya juga terdapat usaha penyelamatan pembiayaan bermasalah. Setiap usaha dalam pemberian pembiayaan pasti mempunyai masalah dan resiko. Begitu pula BMT Mitra Hasanah yang tidak terlepas dari permasalahan atau resiko yang akan dihadapi. Salah satunya resiko tersebut adalah pembiayaan nasabah yang macet. Penanganan pembiayaan bermasalah yang dilakukan adalah sering dan senantiasa datang ke anggota, mencari penyebab permasalahan usaha yang ada, meberi solusi dan jalan pemecahannnya.

Cara yang harus dilakukan yaitu dengan cara 3R (Rescheduling, Reconditioning, Restructuring), bantuan manajemen yaitu diusulkan agar debitur mendapatkan bantuan manajemen dari pihak lain yang lebih menguasai seluk beluk usaha. Apabila dengan cara ini masih juga ada masalah yang timbul baru dilakukan penyelesaian masalah dengan eksekusi barang jaminan. Pengertian 3R yaitu:

a. Rescheduling, yaitu penjadwalan kembali jangka waktu angsuran serta meperkecil angsuran.

b. Restructuring, yaitu perubahan jumlah plafon (menambah atau mengurangi pembiayaan) dan jadwal pembiayaan.

c. Reconditioning, yaitu memperkecil margin keuntungan atau bagi hasil, penundaan bagi hasil, sedangkan nasabah hanya mengangsur pokok terlebih dahulu.

d. Penyitaan jaminan pembiayaan, yaitu meminta jaminan atas uang pada dasarnya bukanlah sesuatu yang tercela. Penyitaan adalah jalan terakhir apabila nasabah benarbenar tidak bisa melunasi pinajamannya, dengan terpaksa harus dilakukan dengan 
penyitaan, maka penyitaan dilakukan kepada nasabah memang tidak bertanggungjawab atas pinjamannya.

\section{Tingkat Kolektabilitas Pembiayaan}

a. Lancar, apabila terjadi tunggakan selama kurang atau sama dengan satu bulan.

b. Kurang Lancar, apabila terjadi tunggakan pembayaran selama lebih dari satu sampai dua bulan.

c. Diragukan, apabila terjadi tunggakan lebih dari satu bulan, usaha masih dapat diselamatkan dengan nilai jaminan $75 \%$ dari tunggakan atau usaha tidak bisa diselamatkan, dengan Jaminan 100\%.

d. Macet, apabila dalam pembiayaan seorang peminjam sudah tidak sanggup lagi untuk membayar angsuran.

Tabel.1 Kolektabilitas pembiayaan

\begin{tabular}{cc}
\hline Kriteria & Presentase \\
\hline Lancar & $85 \%$ \\
Kurang Lancar & $5 \%$ \\
Diragukan & $8 \%$ \\
Macet & $2 \%$ \\
\hline
\end{tabular}

\section{Analisis Penanganan Pembiayaan Mudharabah Bermasalah di BMT Mitra Hasanah}

Pembiayan dalam prakteknya tidak bisa lepas dari yang namanya masalah atau resiko. Masalah tersebut disebabkan karena berbagai faktor, baik faktor intern maupun faktor ekstern. Jika mulai timbul pembiayaan bermasalah maka langkah yang tepat adalah melakukan penyelamatan terhadap pembiayaan tersebut. Penyelamatan tersebut berupa teknik 3R, yaitu (Rescheduling, Reconditioning, dan Restructing). Apabila dari ketiga teknik tersebut masih belum bisa diselesaikan maka langkah terakhir adalah dengan melakukan akad ulang atau eksekusi jaminan. Berikut ini meruapakan penjelasan tentang analisis SWOT (Strength/, Weaknesses, Opportunities, Threat) atau yang biasa disebut dengan analisis kelebihan kelemahan, peluang dan ancaman pada akad pembiayaan mudaharabah di BMT Mitra Hasanah Semarang.

a. Pembiayaan mudharabah di BMT Mitra Hasanah sangat fleksibal dengan prosentase lebih sedikit maka banyak anggota yang memilih untuk mengajukan pembiayaan mudharabah di BMT Mitra Hasanah.

b. Kelemahan pembiayaan mudharabah di BMT Mira Hasanah ini terletak pada prakteknya. Ketentuan bagi hasil kurang maksimal dalam prinsip syariah dan berbenturan dengan realita yang sesungguhnya di masyarakat. Harapan dari BMT Mitra Hasanah adalah semua karyawan dapat memahami prinsip pembiayaan secara syariah dan praktek penerapannya.

c. Peluang pembiayaan mudharabah di BMT Mitra Hasanah adalah pada kenyataannya bahwa BMT Mitra Hasanah ini sangat dibutuhkan oleh semua umat pada umumnya umat Islam yang membutuhkan dana untuk membuat usaha.

d. Ancaman pembiayaan mudharabah di BMT Mitra Hasanah adalah perkembangan lembaga keuangan yang sangat pesat apalagi lembaga keuangan non syariah atau konvensional yang menggunakan tawaran yang lebih canggih untuk lebih menarik minat nasabah atau anggota dengan cara mempermudah transaksi pembiayaannya. Selain itu di dekat BMT Mitra Hasanah juga terdapat BMT BUS yang menjadikan kedua BMT ini menjadi saling bersaing untuk menarik minat anggota. Harapan BMT 
Mitra Hasanah yaitu harus bisa menjadi BMT yang tanggap agar dapat lebi menarik minat anggota daripada lembaga keuangan lainnya.

\section{Penutup}

\section{Kesimpulan}

Berdasarkan hasil analisa deskriptif terhadap data yang kami peroleh dari wawancara dan pengamatan selama melakukan magang tematik di BMT Mitra Hasanah dapat ditarik kesimpulan bahwa:

a. Pembiayaan mudharabah dapat menjadi bermasalah karena beberapa faktor internal dan faktor eksternal.

b. Penanganan pembiayaan bermasalah yang dilakukan adalah sering dan senantiasa datang ke anggota, mencari penyebab permasalahan usaha yang ada, memberi solusi dan jalan pemecahannnya dengan cara 3R (Rescheduling, Reconditioning, Restructuring).

\section{Saran}

a. Hendaknya BMT Mitra Hasanah lebih letiti dalam melakukan survei sebelum memberikan pembiayaan kepada anggota agar tidak terjadi manipulasi data yang berakibat pada kelangsuran pembayaran angsuran nantinya.

b. Diharapkan SDI (Sumber Daya Insani) BMt Mitra Hasanah dalam era globalisasi ini dapat meningkatkan pengetahuannya dan lebih mengenalkan BMT Mitra Hasanah ke masyarakat luas sehingga banyak masyarakat yang akan percaya dengan lembaga keuangan syariah khususnya BMT Mitra Hasanah.

\section{Daftar Pustaka}

Anjarsari, Mega, 2012, Strategi Penanganan Pembiayaan Mudharabah Bermasalah Studi pada KJKS BMT Marhamah Kantor Cabang Leksono. Tugas Akhir

Buchori, Nur Syamsudin, 2012, Koperasi Syariah Teori \& Praktik. PAM Press, Tangerang

http://danifsunny.blogspot.co.id/2014/05/pembiayaan-bermasalah-perbankan -syariah.html, diakses pada tanggal 9 Septermber 2016 pukul 17.28 WIB

http://khanaqwa.blogspot.com/2011/06/penangan-pembiayaan-bermasalah-bank.html, diakses pada tanggal 6 September 2016 pukul 17.13 WIB

Masruroh, Sri Hayati, 2014, Penangan Pembiayaan Bermasalah dalam Akad Mudharabah di BMT Harapan Ummat Kudus. Tugas Akhir

Prabowo, Baya Agung, 2012, Aspek Hukum Pembiayaan Mudharabah pada Perbankan Syariah. UII Press, Yogyakarta

Sjahdeini, Sutan Remy, 2014, Perbankan Syariah. Kencana Prenamedia Group, Jakarta

Wawancara dengan Ibu Richaul Wardah, A.Md, selaku Akunting di BMT Mitra Hasanah

Wawancara dengan bapak Cahyo Adi Saputro, selaku bagian Pembiayaan di BMT Mitra Hasanah 